\title{
Teaching NeuroImages: Diffuse intrinsic pontine glioma in white matter
}

Victor M. Lu, MD, PhD, Desmond A. Brown, MD, PhD, Alfredo Quiñones-Hinojosa, MD,

Kaisorn L. Chaichana, MD, and David J. Daniels, MD, PhD

Neurology ${ }^{\circledR}$ 2020;95:e608-e609. doi:10.1212/WNL.0000000000009927

Figure MRI of diffuse intrinsic pontine glioma (DIPG) with overlaid tractography

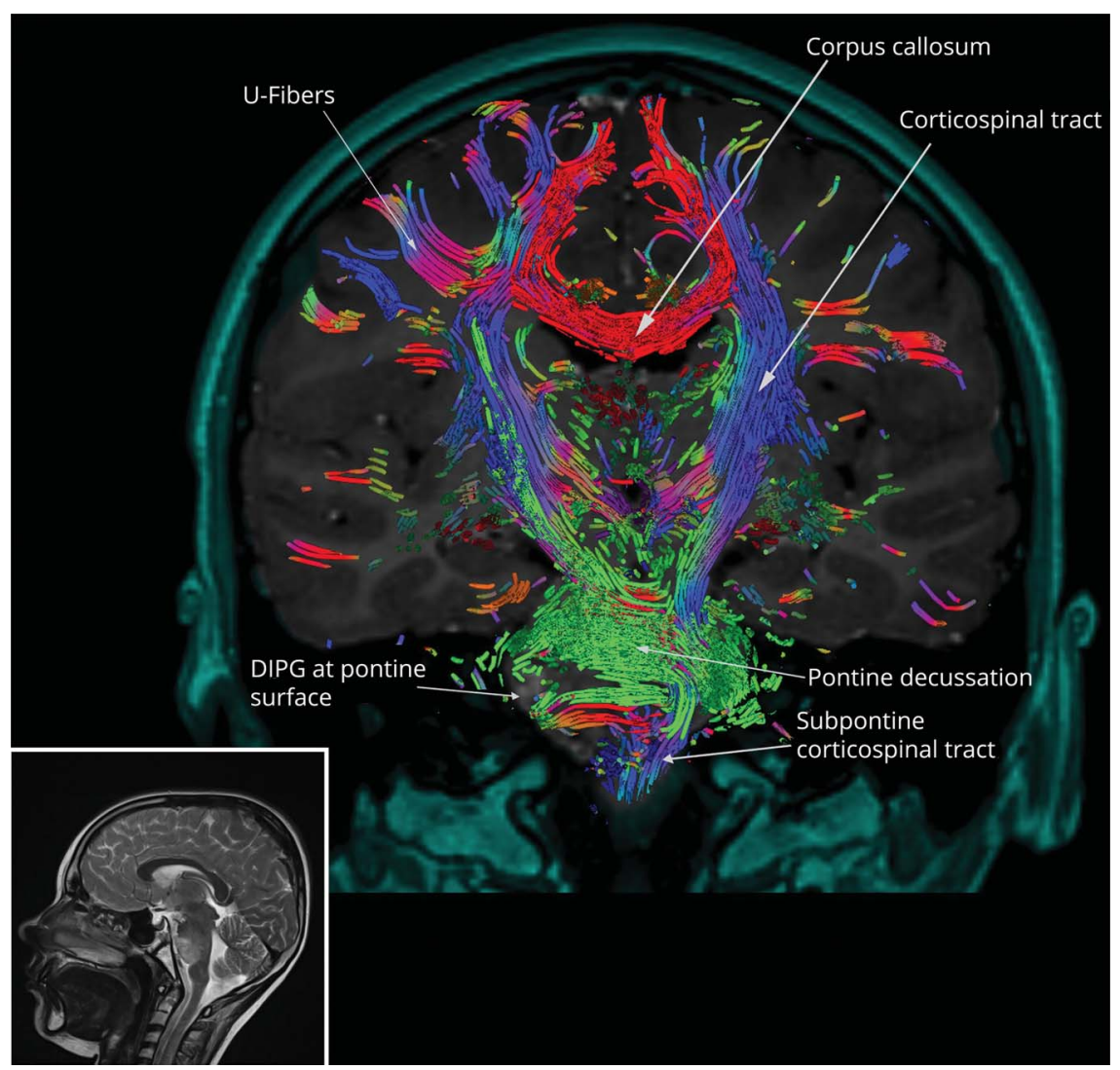

Coronal T1 gadolinium-enhanced MRI of DIPG with overlaid tractography, with sagittal T2 MRI provided for reference. This image was generated by Synaptive Modus Plan software featuring BrightMatter AutoSeg (Synaptive Medical Inc., Toronto, Canada).

We present an image of diffuse intrinsic pontine glioma (DIPG) showing its relationship to white matter structures based on reconstructed tractography (figure). An 8-year-old girl presented with diplopia, right abducens nerve palsy, and mild ataxia. Reconstruction showed at the level of the pontine decussation a right-sided disruption of the pontocerebellar fibers anterior to the descending corticospinal fibers involving the pontine nuclei region. Understanding the white matter tract anatomy of DIPG in relation to surrounding structures

\author{
Correspondence \\ Dr. Daniels \\ daniels.david@mayo.edu
}


critical for function by this method may have the potential to assist in minimizing functional deficit risk during biopsy, but requires future validation.

\section{Study funding}

No targeted funding reported.

\section{Disclosure}

The authors report no disclosures relevant to the manuscript. Go to Neurology.org/N for full disclosures.
Appendix Authors

\begin{tabular}{lll}
\hline Name & Location & Contributions \\
\hline $\begin{array}{l}\text { Victor M. Lu, MD, } \\
\text { PhD }\end{array}$ & $\begin{array}{l}\text { Mayo Clinic, } \\
\text { Rochester, MN }\end{array}$ & $\begin{array}{l}\text { Drafted the manuscript for } \\
\text { intellectual content }\end{array}$ \\
\hline $\begin{array}{l}\text { Desmond A. Brown, } \\
\text { MD, PhD }\end{array}$ & $\begin{array}{l}\text { Mayo Clinic, } \\
\text { Rochester, MN }\end{array}$ & $\begin{array}{l}\text { Drafted the manuscript for } \\
\text { intellectual content }\end{array}$ \\
\hline $\begin{array}{l}\text { Alfredo Quiñones- } \\
\text { Hinojosa, MD }\end{array}$ & $\begin{array}{l}\text { Mayo Clinic, } \\
\text { Jacksonville, FL }\end{array}$ & $\begin{array}{l}\text { Revised the manuscript for } \\
\text { intellectual content }\end{array}$ \\
$\begin{array}{l}\text { Kaisorn L. } \\
\text { Chaichana, MD }\end{array}$ & $\begin{array}{l}\text { Mayo Clinic, } \\
\text { Jacksonville, FL }\end{array}$ & $\begin{array}{l}\text { Revised the manuscript for } \\
\text { intellectual content }\end{array}$ \\
$\begin{array}{l}\text { David J. Daniels, } \\
\text { MD, PhD }\end{array}$ & $\begin{array}{l}\text { Mayo Clinic, } \\
\text { Rochester, MN }\end{array}$ & $\begin{array}{l}\text { Revised the manuscript for } \\
\text { intellectual content }\end{array}$ \\
\hline
\end{tabular}




\section{Neurology}

\section{Teaching NeuroImages: Diffuse intrinsic pontine glioma in white matter \\ Victor M. Lu, Desmond A. Brown, Alfredo Quiñones-Hinojosa, et al. \\ Neurology 2020;95;e608-e609 Published Online before print July 13, 2020 \\ DOI 10.1212/WNL.0000000000009927}

This information is current as of July 13, 2020

\section{Updated Information \& Services \\ Subspecialty Collections}

Permissions \& Licensing

Reprints including high resolution figures, can be found at:

http://n.neurology.org/content/95/5/e608.full

This article, along with others on similar topics, appears in the following collection(s):

\section{All Pediatric}

http://n.neurology.org/cgi/collection/all_pediatric

\section{MRI}

http://n.neurology.org/cgi/collection/mri

Primary brain tumor

http://n.neurology.org/cgi/collection/primary_brain_tumor

Information about reproducing this article in parts (figures,tables) or in its entirety can be found online at:

http://www.neurology.org/about/about_the_journal\#permissions

Information about ordering reprints can be found online:

http://n.neurology.org/subscribers/advertise

Neurology ${ }^{\circledR}$ is the official journal of the American Academy of Neurology. Published continuously since 1951, it is now a weekly with 48 issues per year. Copyright (C 2020 American Academy of Neurology. All rights reserved. Print ISSN: 0028-3878. Online ISSN: 1526-632X.

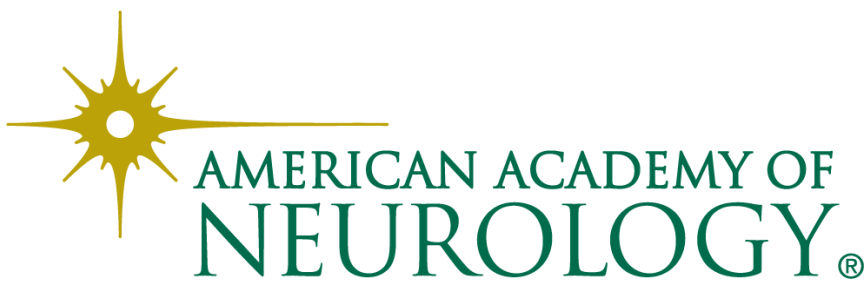

